\title{
The Challenges to the Protection of Women Against Domestic Violence in Jimma Zone, Oromia Regional State, Ethiopia
}

\author{
Lamessa Gudeta Guder ${ }^{1}$ (L.L.B, L.L.M) \\ Oromia regional state justice office, Oromia, Ethiopa
}

\begin{abstract}
Domestic violence against women is one of the scourge and pervasive violence directed against women by their; current or former husband, current or former boyfriends and other friends who has sexual relation with the women. It has numerous and devastating physical and psychological consequences for the victim. Victims of domestic violence experience both short-term and long-lasting health outcomes including death, grave physical injury, reproductive health, unwanted pregnancy, sexually transmitted diseases, depression and suicidal behavior. However, despite of its devastating consequence, its prevalence is very high and the problems are socially condoned in Ethiopia and specifically in Jimma zone. This clearly indicates that the protection of women against domestic violence in the Jimma zone has been not succeeded which manifests the existence of challenges and obstacles. Hence, the aim of this article is to identify the challenges to the protection of women against domestic violence. To this end, the Ethiopian policy and laws regarding domestic violence are analyzed, the practical commitments of law enforcement authority of Jimma zone and socio-cultural and religious of Jimma zone community are evaluated in lights of the rights to women against domestic violence. Accordingly, the research identifies different challenges to the protection of women against domestic violence in Jimma zone which includes; legal gap, practical challenges, socio-cultural, socio-economic and religious challenges dominantly. Therefore, unless, take action upon the identified challenges, the women's human rights will continuously to be violated. Hence, lastly to this end, the researcher arrived at the set of recommendations.
\end{abstract}

Keywords: Domestic violence against women, the challenges, Laws and policy, Ethiopia, Jimma Zone, Law enforcement authority, socio-cultural, legal instruments.

DOI: $10.7176 / \mathrm{JAAS} / 55-04$

Publication date:May $31^{\text {st }} 2019$

\section{Introduction}

Domestic violence is one of the most pervasive forms of violence against women and an act which directed against women by their intimate partners ${ }^{1}$ either current or former spouses and or boyfriends or other family members in the world which affects all women regardless of their color, identity, status, nationality and or age. It leads to serious health damage, and often may end fatally. ${ }^{2}$ Apart from physical, sexual and economic injuries, it causes psychological injury; fear, distress, loss of self-confidence ${ }^{3}$ which even more harmful than the physical pain. It destroys a woman's self-esteem and the capacity for resistance ${ }^{4}$ against such degrading and humiliating incidence of domestic violence. It can obliterate the personality of women in such a way that it becomes a serious assault on human dignity which is a core concept of human rights law. ${ }^{5}$

It is highly prevalent, especially in rural areas such as Jimma zone districts and widely socially condoned. Although in some extent, the Ethiopian law and law enforcement institutions condemn the violence against women, domestic violence against women remain widely practiced in many parts of (Jimma zone) ${ }^{6}$, south western Ethiopia. Some studies ${ }^{7}$ reveal the pervasiveness and prevalence of these problems in the south western Ethiopia which includes Jimma zone. Though, there are different legal safeguards in international or regional instruments which Ethiopia ratified to protect women against violence which possibly may include domestic

\footnotetext{
1 UN Dep't of public information, Unite to ending violence against women (Factsheet, DPI/2498 Feb. 2008) $<$ http://www.un.org/en/women/endviolence/pdf/VAW.pdf $>$ accessed 23 December 2019, see also the definition of VAW given under united nations (U.N. Resolution adopted by the General Assembly, 61/143.19 ${ }^{\text {th }}$ December 2006)

${ }^{2}$ Council of Europe, Preventing and Combating Domestic Violence against Women (A learning resource for training law enforcement and justice officers, Council of 2016) $<$ https://rm.coe.int/CoERMPublicCommonSearchServices/DisplayDCTMContent >accessed 20 December 2019

3 Ibid

${ }^{4}$ R. Copelon, 'Recognizing the egregious in the everyday: Domestic violence as torture' (1994) 25 Columbia Hu R Law Rev

${ }^{5}$ C. Romany, 'State responsibility goes Private: A Feminist Critique of the Public/Private Distinction in International Human Rights Law' in R. Cook (edn), Human Rights of Women: National and International Perspectives (University of Pennsylvania Press, Philadelphia 1994$) 85$.

${ }^{6}$ Based on the 2007 Census conducted by the CSA, this Zone has a total population of 2,486,155, an increase of $26.76 \%$ over the 1994 census, of whom 1,250,527 are men and 1,235,628 women; with an area of 15,568.58 square kilometers, Jimma has a population density of 159.69. While 137,668 or $11.31 \%$ are urban inhabitants, a further 858 or $0.03 \%$ are pastoralists. A total of 521,506 households were counted in this Zone, which results in an average of 4.77 persons to a household, and 500,374 housing units. Jimma is located $335 \mathrm{~km}$ south west of the Ethiopian capital, Addis Ababa. Currently the town is serving as a political and economic center of the Jimma zone.

${ }^{7}$ Mussie Kassa G/Mehidn, Intimate partner violence: prevalence, risk factors and attitude of men and women in Jimma Zone, Ethiopia (Master Thesis on Epidemiology and public Healthy University of Umea,2006) unpublished
} 
violence, prevalence of domestic violence against women and pervasiveness of domestic violence in every part of the Zone are high. Such high records of violence pave the way for violation of women's human rights in Jimma zone. So, domestic violence against women has very adverse effect on the protection and upholding women's human rights throughout the Zonal districts. Unless such domestic violence against women would be prevented and women's human rights are ensured, its effect is not only upon women rather upon the community as a whole.

\section{Methodology of the study}

In this study the researcher mainly aimed to identifying the challenges to the protection of women against domestic violence from professional standpoint. Therefore, qualitative methodology was primarily used. The study was applied to examining individual, situational, practical gap, legal and socio structural risk markers for domestic violence in this study. As such, in terms of source of data, both primary and secondary resources were employed in the study.

\subsection{Target populations}

As I have already mentioned in the background, Jimma zone has comprises of twenty-one districts/woredas including Jimma town special zone. For this research purpose, among 21 district/woredas/ of Jimma zone; 5 (kersa, seka chokorsa, Mana, Goma and Omo Nada) districts has been taken and Jimma town special zone has been selected purposively because of high population concentrations.

From the selected districts, target population has been selected purposively from the institutions working on DVAW and it includes some NGO's. The institutions working on protection of WADV specifically included in target populations were Justice Office, Courts police stations and women and child affairs office. As such, the NGO's are from the Jimma town those who are working on the women and children.

The existing legal documents of the country such as domestic policy, legislation, directives and guidelines has been used to identify and evaluate the existing policy and legal frame work against domestic violence in the country. The research mainly depends on semi-structured interviews with a list of identified topics to cover and focused group discussions. From the selected districts; FGD and interview has been conducted with selected professional in courts, justice office, police investigation departments, women and child affairs office in each respective selected woredas/districts and some NGOs.

For the purpose of interview, 10 informants have been selected purposively from the selected professional members of each selected districts and 4 informants of NGOs from Jimma town. Then (10 informants $\mathrm{x} 6$ district) +4 informant $=64$ informants has been interviewed.

For the purpose of Focused group discussion, one FGD have been conducted from the selected professional in each selected districts. Each FGD contain 6-8 members. The total - 1 FGD x 6 district=6 FGD have been conducted.

\subsection{Data analyzing methods}

The researcher used interpretational analysis approach and descriptive for this study. Each session was followed by preliminary analysis that included verbatim transcription of Oromic translation into English, and continuing the data collection until a point of saturation. The most critical step of interpretational data analysis taken place in this study was developing a set of categories that adequately encompass and summarize the data. Accordingly, the data generated from focus group discussion and in depth interview were divided in to different categories/themes. Categories were formed keeping the objective of the study in mind as much as possible and similar categories were brought together. Accordingly, the major concepts were interpreted by repeated reading through the categories, notes and memos, summarizing, and then verified.

\section{Discussion and Findings Parts}

The challenges to the protection of women against domestic violence were mainly drawn from in-depth interview and focused group discussion conducted with different participants. ${ }^{1}$ Discussion was made that depicts the challenges and obstacle by pinpointing different legal, practical, socio-cultural, religious and socio-economic challenges to the fighting of domestic violence against women. The data obtained from participants shows that, the ways by which the human rights protection of private and family life is sometimes understood are one and the major of the challenges facing women's protection against domestic violence in Jimma zone. The overwhelming majority of physical, sexual, psychological and economic violence takes place within close social confines, at home, and sadly is part of everyday life of many women.

Accordingly, a number of challenges have been highlighted by key informants from the law enforcement

\footnotetext{
${ }^{1}$ Participants were drawn from professionals of court, justice office, police station, womens and child affairs office at kersa district, omo Nada district, Gomma district, Limmu Sakka districts, Mana district and some NGOs at Jimma town secial zone.
} 
bodies as well as professional members and different NGOs working on the women and child that took part in FGDs and different interviews. These challenges may include the legislative gap, giving weak attention to incidence of domestic violence (practical gaps), socio-cultural and socio-economic challenges, religious teachings and misconception about domestic violence on parts of women. I will discuss them briefly in this main topic and analyze them one by one in the subsequent sub-topics.

\subsection{Legislative challenges to the protection of women against domestic violence.}

In proceeding chapter, under one sub-topic, we have seen the Ethiopian laws and policy in light of international human rights instruments regarding domestic violence. However, under these sub-topics, I will try to show the way in which our legislation has been considered as the challenges to protection of women against domestic violence in Jimma zone.

Building strong legal frame work is a cornerstone for the protection of women's rights against any sexual based discrimination and violence. Accordingly, targeting at providing better protection to the rights of women, Ethiopia has attempted to undertaken significant 'gender-sensitive' legislative reforms after the down fall of military junta. Foremost among these laws; the 1995 FDRE constitution, the 2003 Revised Family Law ${ }^{1}$ and the 2005 Revised Criminal Code $^{2}$ are indicative . The principle of equality is enshrined in the Constitution of the country as well as all relevant subsidiary legislation. Further, the Constitution provides that internationally agreed standards ratified by the country as integral part of the Ethiopian law. ${ }^{3}$ Accordingly, the international standards adopted in instruments ratified by Ethiopia like $\mathrm{CEDAW}^{4}$ constitute part of the law of the land.

However, regarding the scope of coverage of laws dealing with VAW, the Ethiopian legal framework cascades dump of the internationally accepted standards. Different forms of violence against women have not be criminalized in the way of understanding the complexity nature of the violence though international standards require States to ensure that forms of violence against women are included in criminal law as criminal acts.

\subsubsection{Inadequacy of Legal responses to criminalizes patterns of DVAW and punishment of perpetrators}

Criminalizing offences of gender based violence is considered as major step in the protection of women's rights against any abusive acts of perpetrators. Because- legal framework is the first measures that needs to have been taken to illegalize or legalize certain acts. Accordingly, Ethiopia has enacted FDRE criminal code.

The Revised Criminal Code of the Federal Democratic Republic of Ethiopia (The Criminal Code, 2004) is the major areas of Ethiopian law that has been revised in conformity with the FDRE constitution and includes different new and revised provisions that are of pertinent to the protection of women from violence by criminalizing different offences. The Code addresses violence against women in different forms. Accordingly, the code criminalizes most forms of violence against women and girls including rape outside wedlock, trafficking of women, prostitution of another for gain, and physical violence within marriage or in an irregular union- to some extent, abduction, Female genital mutilation, and early marriage. ${ }^{5}$

As we understand from the provision of FDRE Criminal code, though, the criminal code criminalizes different forms of violence against women; it doesn't give much attention to the domestic violence against women. However, domestic violence is not simple and forgettable violence since it has consequences of serious healthy, economic and social problems as discussed in chapter two. The majority of participant in FGD raised that, the FDRE criminal code doesn't criminalize many forms of domestic violence against women and DVAW did not have much attention in this criminal code. Undeniably, such kind of assertion is valid as everyone can understand from criminal code.

Therefore, such legal lacuna may be great challenges for our justice system in protection of WADV in general and particularly in Jimma zone. It is better to see and discusses the legal challenges to the patterns of abuses and evaluate the legal responses of our laws to outlaw; the physical, sexual, psychological and economic abuse in the following sub-topics.

\subsubsection{The Legal responses to Physical violence against women}

Physical abuses are high prevalence in Jimma zone and most of the women are battered by their husband in each single day. Many participant of FGD conducted in six districts of Jimma zone reveal that, the abuse extends from slap to the use of weapons resulting in death. Most of them bore visible scare, bruise and cuts on their bodies. Despite the gravity of the problems, our criminal code doesn't give much attention as such. The code has not put comprehensive definition and scope of the term violence against women as was done under the CEDAW and/or

\footnotetext{
${ }^{1}$ The Revised Family Code of Ethiopia, Proclamation No. 213/2000

${ }^{2}$ Criminal Code of the Federal Republic of Ethiopia, proclamation no. 414/2004

${ }^{3}$ The Constitution of the Federal Democratic Republic of Ethiopia, Proclamation No. 1/1995 Article 9(4)

${ }^{4}$ Convention on the Elimination of All Forms of Discrimination Against Women (adopted 18 December 1979, entered into force on 3

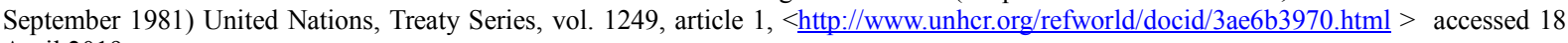
April 2019

${ }^{5}$ FDRE Criminal code (n 179) -see provision; trafficking women ( article 597), prostitution of another for gain (article 634), and physical violence within marriage or in an irregular union ( article 564), abduction, ( articles 587, 590), Female Genital Mutilation ( articles 565-6), and early marriage (article 649).
} 


\section{African Protocol. ${ }^{1}$}

Domestic violence is dealt under the provision on violence against a marriage partner or a person cohabiting in an irregular union. The law treats this kind of violence in the same manner as any form of assault committed on any person irrespective of the nature of the crime. However, cases of DVAW have special characteristic features. For example they are committed repeatedly, occur in situations where the woman is under the influence of the man; mainly where she is economically dependent, it is a manifestation of power of men over women. Also the crime of DVAW is committed at behind the closed door in hidden place and complex phenomena, committed in the situation even evidence cannot be obtained to press the criminal charges against the perpetrator. As such, it is sexual oriented violence which occurs up on the relationship between the perpetrator and the victim- in the situation where a victim owes believes to the perpetrator up on their special relationship.

Physical VAW is an act of violence that results in physical harm and/or suffering to women and is perpetrated against women because of their gender. This aspect of the definition is missing from the law as the law deals with cases of DVAW by making cross-reference to cases of assault and willful injury. Article 564 is the single provision with explicit reference to the term domestic violence in the code. The excerpt of this article read as,

\section{Violence against a Marriage Partner or a Person cohabiting in an Irregular Union.}

The relevant provision of this Code (Arts. 555 - 560) shall apply to a person who, by doing violence to a marriage partner or a person cohabiting in an irregular union, causes grave or common injury to his

\section{/her physical or mental health. ${ }^{2}$}

The problem is that , this article is not only narrowed the type of domestic relationships to marriage partner and person co-habiting in an irregular union but also refers back to the provisions dealing with crimes against person and health (Articles 555-560) for determination of its criminality and punishments. It seems like simple incidental statement; the code has not as such created an offence of domestic violence in its own right in separate and clear provisions. Rather humbly it assimilates to ordinary assault and battery; grave or willful physical injuries.

As such it fails to recognize a crucial element of DVAW that, it is violence perpetrated against women because they are women. It doesn't consider the special nature of domestic violence, where the victim is usually in a relationship of dependence with the perpetrators. Rather, merely equating cases of DVAW to assault and treating them as such, the law fails to take into account these gendered features.

At this juncture, it is worthy to raise the issue that, does article 564 of FDRE criminal code adds something to protection of women against DV? As mentioned above, it simply refers to Arts. (555-560) ${ }^{3}$. We can understand from this provision that, even when article 564 were not included in FDRE criminal code, the enforceability of Article (555 - 560) is inevitable. This indicates that inclusion and, or exclusion of article 564 has no effects on the enforceability of Article (555 - 560) for all physically abused persons including intimate partner abuse. Hence article 564 has added nothing special to the protection of women against domestic violence.

This in turn shows that, physical abuse against women in domestic sphere does not properly addressed as much as needed in FDRE criminal code. Such legal lacuna has been manifested in practice in most parts of the zone as challenges to protection women against domestic violence.

\subsubsection{The Legal response to sexual violence against women}

Women's experiences with sexual violence varied along a ranging from battering rape and bullying to threats, verbal humiliation and non-physical forms of pressure that compelled them to engage in sex against their will. ${ }^{4}$ In an abusive relationship, sex is just another form of male control in an effort to gain the woman's complete acquiescence. These strategies of control often focused directly on the female victim's body and sexuality. As data obtained from participants, the forced sexual act becomes one; in which the woman is silenced, controlled and subordinated.

Sexual violence in marriage is clearly an issue of gender inequality, in which a woman is forced to give in to her husband's demands. ${ }^{5}$ Women experienced rape or physically forced sex in the context of a battering relationship. The data gathered from FGD show that, Women are not willing to call their experiences as rape, which could be a sign that the concept of marital rape is rather absent in the Ethiopian culture.

\footnotetext{
${ }^{1}$ African Union, Protocol to the African Charter on Human and Peoples' Rights on the Rights of Women in Africa, 11 July 2003 , UN, Commission on the Elimination of Discrimination Against Women, General Recommendation No. 19: Violence Against Women, 11th Sess., 4, U.N. Doc. A/47/38 (1993)

${ }^{2}$ FDRE Criminal Code(n 10) Article 564

${ }^{3}$ Ibid Article 555-560

${ }^{4}$ Myhill A, et al, Rape and Sexual Assault of Women: The Extent and Nature of the Problem: Findings from the British Crime Survey (Home Office Research, Development and Statistics Directorate 2002)42.

${ }^{5}$ Pracher M , 'The Marital Rape Exemption: A Violation of a Woman's Right of Privacy' (1981) 11 Golden Gate University L Rev.3
} 
Sexual assault including rape and sexual harassment by outsider are addressed with in the criminal law. However, the provision on rape clearly excludes instances of marital rape. The data congregated from participants of FGD in justice office indicate that, the exclusion of marital rape from rape punishable by law under the Ethiopian Criminal Code contributes to the prevalence of marital rape in Jimma zone. Since there are no legal consequences for rape committed within wedlock, men continue to rape their wives, and this has severe physical and psychological repercussions for such victims.

The right to refuse sex in marriage is not accepted and still remains 'unthinkable' for all women and men in zonal districts. This clearly excludes the majority of cases where by hostile working, living and learning environments are created due to the threat caused by demands of sexual favors. In 100 countries across the world, marital rape is a criminal offence and is punishable by law. ${ }^{1}$ For instance; in South Korea, Japan, Philippines and Taiwan, marital rape has been criminalized.

In Ethiopia, however, marital rape is not considered to be a crime under the Ethiopian criminal law system. When we see article 620 of FDRE Criminal code, it apparently legalized the wedlock rape. It excerpt read as,

\section{(1) Whoever compels a woman to submit to sexual intercourse outside wedlock, whether by the use of violence or grave intimidation, or after having rendered her unconscious or incapable of resistance, \\ is punishable with rigorous imprisonment from five years to fifteen years.}

On this juncture, the phrase 'outside wedlock' clearly indicates, the legality of wedlock rape which has consequences of great healthy and psychological problems on the victim. Although the CEDAW Committee urged Ethiopia to amend its criminal law in order to criminalise marital rape, in its concluding observations on the country in 2011, the legislature still failed to comply with the request of the Committee. ${ }^{2}$ It exempts rape committed within wedlock from punishment. As raised by participants of interviews, due to the exemption of marital rape from punishment under the Criminal Code, men have been using their marital status as a license to rape their wives. And law enforcement authorities by themselves have been abstained from interfering into sexual abuse between intimate partners.

For instance, one prosecutor quotes that, "most of the time, sexually abused women has been coming to investigation office, however, we could not conduct investigation on this issue since we have no legal support. we simply send back them to home, or order to go to court to seek divorce and hospital to treatment.",

The fact that the Criminal Code does not recognised marital rape as a crime discourages the police from conducting investigations and taking action. Many data assembled from participants in interview conducted with judges, prosecutors and police reveal that, decriminalization of marital rape is preventing them even from investigation and prosecuting the alleged offender. Other participants pinpoint that, due to the lack of relief after reporting incidents of marital rape, women are discouraged from making further reports when the incident is repeated.

\subsubsection{The Legal response to Psychological violence against women}

As the results of the literature and the participants of focused group discussion shown; insults, belittling, verbal aggression and constant humiliation are the common forms of psychological violence directed against women in Jimma zone. The participants of interview conducted with professionals of women and child affairs office often say that the psychological abuses and degradation are even more difficult to bear than physical abuse. Verbal humiliation, such as being called names, sworn at or put down were seen and reported in most parts of the zonal districts. It has been manifested and reported through seeking divorce in civil cases rather than through criminal proceedings. For instance, one Judge quotes that,

"Psychological abuse is one of the causes of divorce in addition to other abuses.

Most of the time, when women faced $D V$, they do not want to criminal

remedies to their abuse rather they seek divorce in the court of law.

And DV is the very causes for the increments of divorce." 4

\footnotetext{
${ }^{1}$ Sharma K , Behind the Locked Doors: The Evil of Marital Rape, <http://www.mightylaws.in/1246/locked-doors-evil-marital-rape > accessed 4 April 2019

${ }^{2}$ Committee on the Elimination of Discrimination against Women, Concluding observations of the Committee on the Elimination of Discrimination against Women-Ethiopia Forty-ninth Session,11-29 July, 2011, para 21.

${ }^{3}$ An interview conducted with prosecutor by researcher on 22 April 2018

${ }^{4}$ An interview conducted with the court by researcher on 21 April 2018
} 
From this we can understand that, the problem of legal gap in criminalization of domestic violence abuses leads to the increments of divorces. And the anger of violence are manifested through divorce. Violence described in terms of emotional or psychological abuse, referring to situations in which a man might constantly insult or undermine a woman. And Women disproportionately suffer from these types of violence because they are women. As data gathered from participants of FGD held with prosecutor shows, it has very adverse effects on women inter alia, demoralized women and trapped in abusive relationships, make them perceived as inferior to men cognitively, and make them to be submissive, obedient and respectful of their husband. It hart women's self-confidence and makes them to be emotionally dependent.

However, the Ethiopian law doesn't give attention to such humiliating nature of psychological violence against women and treat similar to other ordinary insult, or threat. The law treating these forms of violence irrespective of the sex/gender of the perpetrator and victim as well as the prevailing gender relations fails to capture and address the gendered nature of the violence.

When we see the FDRE criminal code thoroughly, there are different ordinary provisions applicable to any person irrespective of sexual relationships, or social status and, or other parameter which aimed to criminalize some psychological harms. For instance article (607-619) of FDRE criminal code talks about Crimes against honours or reputation, defamation and calumny, insults or outrage. ${ }^{1}$ On other hand Article (580-585) criminalizes the offence of intimidation, threat to accusation or disgrace, coercion, deprivation of power of decision and illegal restraints. ${ }^{2}$ These wordings of provision don't consider any special nature of psychological violence directed against women. It simply stipulates the provision applicable to any person and it did not benefit women because of special nature of domestic violence against women which needs to give more attention in all circumstances of investigation and prosecution.

Accordingly, although the law recognizes psychological harm, the coverage is not adequate for protection of women against domestic violence since it does not take into account the complexity nature and hidden commission of DVAW which in turn needs to promulgate special and separate laws to guide all the process of obtaining evidences and the prosecutions of DV cases. For instance many countries including Latin American countries have enacted specific domestic violence laws that combine criminal offences and civil protections. Most of these laws include psychological violence in the definition of domestic violence. ${ }^{3}$

\subsubsection{The Legal response to Economic violence against women}

Economic abuse is another form of abuse in which women are the primary victims. Men have traditionally controlled and dominated the financial assets of the family, and have retained the power to make financial decisions within the family. As data gathered from participants of FGD conducted with professionals of womens and child affairs office shows, there are different reports; economic or financial abuse involves the control of the use and availability of money, preventing her participation in money-spending decisions and refusing to give her money for basic household necessities. It involves an act that aimed at disempowering women by denying them access to and control over basic resources. When women fail to comply with their demand, they can punish and threatening them by refusing to give them money and physically assaulting them. Financial domination; like psychological, physical and sexual abuse, has the great negative effects on women's emotional, social and physical well-beings.

However, the issue is that, our laws seem to ignore such old-scourge economic abuses directed against women. The absence of appropriate legal frame work to punish such perpetrator of economic violence leads to validation of such abuse against women. For instance, if a husband refuses to his wife to access health care by denying her resources/money, control of the use and availability of money, preventing her participation in money-spending decisions and refusing to give her money for basic household necessities what is the available legal recourse?

The participants of interview explain their concern regarding the absence of specific legal framework against the economic abuse directed against women. They added that, there are no ways to distinguish the acts that constitutes a domestic violence even to those persons. For instance it has not taken into consideration the different aspects of domestic violence such as the economic abuse. All these clearly show that, the Ethiopian laws don't recognize in preventive manner the forms of domestic violence against women. This in turn makes DVAW as lawful act which has great challenges to the protection of women ADV in Jimma zone.

\subsubsection{Absence of protection order for Victims or Survivors (civil remedy)}

In proceeding topics, we have discussed the inefficiency of our laws to criminalizing patters of domestic abuses. But under this topic we try to look whether civil remedies-protection order were not available for victims in our laws. The data gathered from the participants of interviews divulge that, Ethiopian law is deprived of specific

\footnotetext{
${ }^{1}$ FDRE Criminal code (n 10) article (607-619)

${ }^{2}$ FDRE Criminal code (n 10 ) Article (580-585)

${ }^{3}$ UNDAW, Good practices in combating and eliminating violence against women, United

nations division for the advancement of women (17-20 May 2005 Vienna, Austria) 12
} 
civil remedies against domestic violence. There has been no separate domestic violence act or law which provides specific civil remedies for victims/survivors which includes; the right to obtain protection order, actions for damages against the perpetrator, the police or third parties who fail to prevent the violence, governmental victim compensation funds, monetary/compensation relief, custody order, residence order, shelter or medical benefits or more than one such order.

As such protection orders are essential criminal or civil justice measures aimed at preventing further violence from happening and protecting victims. The participants of FGD conducted with judges explain that, such remedy has of paramount importance for victims. It provides victims with time to reflect on what their options are in terms of safety, and to decide about their future.

The protection orders serves as a deterrent measure. Because, it send messages to the perpetrators that, their behaviour is not acceptable and that there will be consequences for their actions. Such measures also prevent the perpetrator from approaching or contacting the victim or allow the removal of the perpetrator from the joint dwelling or that of the victim for a specific period of time. The purpose of restraining or protection orders is to offer a fast legal remedy to protect people at risk.

Many participants of interviewed support the necessity of protection order. If there are protection orders, it is better for the victim, even it prevent the double victimization, shorten the process of remedy to victim, give high protection in simple procedure. One informant from professionals of women and child affairs office told me that,

\section{"Abused women (physical, sexual and psychologically injured) reported to us. \\ We cannot give any protection order to victims, nor court order protection directly rather than stringent procedure through police which is very difficult}

for abused women. We simply call the abuser and warned. Then we send back both the victim and abuser. But after that, abuser abused victim again.

We remembered the circumstance, when abuser chopped the victim in to pieces and kill her after went to home,"l

It is encouraged that both criminal and civil remedies should be made available for the effective prevention and redress in cases of violence against women. In Ethiopia, there is tort law provided in civil code under article $2035^{2}$ regarding for the compensation to the arisen damage. However, it is not adequate and out dated in terms of amount of compensation and coverage. It does not consider the unique nature of domestic violence against women. It has no protection order in case of domestic violence. On the other hand, the system of a tort action provided in civil code will not address immediate needs of women's reality. Therefore, such problem prays the enactment of complied DV law which may include all possible civil remedy and different protection orders along with criminalization.

Many countries include civil remedies in their domestic violence law. ${ }^{3}$ For instance, in the United States, victims of violence can seek civil damages from the perpetrator for infliction of violence, and in some circumstances, from the police or other actors who should have prevented the violence but failed to do so.

\subsection{Inadequacy of Law enforcement authorities response to DVAW and absence of victim's protection in Jimma zone}

In proceeding sub-topics, I have discussed the legal lacuna as one challenges regarding the protection of women against domestic violence. However, in this topic we will try to see the practical gaps perceived around the law enforcement authorities those who entrusted to uphold and protect WADV.

It is incontestable that, one of the mechanisms of protecting women against domestic violence is ensuring prosecution and punishment of perpetrators of DVAW and, as well as giving due attention for protection of victims. A number of preconditions need to be fulfilled to undertake prosecution of perpetrators and protection of women against violence. Primary amongst, the establishment of institutional structures of law enforcement as well as empowering them with all logistic and necessary budget, establishing gender sensitive criminal proceedings including; investigation, evidence gathering, prosecution and the like.

However, in Jimma zone, a number of challenges have been highlighted by key informants from the law enforcement bodies as well as professional members that took part in FGDs and different interviews regarding the practical gaps. The low level of prosecution and punishment of perpetrators of DVAW are demonstrated. The data gathered from the informant of professionals of women and child affairs office and NGOs show that, domestic violence case did not investigated and brought to court promptly. Even there are a number of times were the perpetrators of violence go unpunished when brought to prosecutor and, or courts.

Therefore the majority of data reveal that, the many reported cases of violence against women are not

\footnotetext{
${ }^{1}$ Interviews conducted with professional of women and child affairs by the researcher at Jimma town on 12 April 2018

${ }^{2}$ Civil Code of the Empire of Ethiopia, Proclamation No. 165 / 1960 Article 2035

${ }^{3}$ UNDAW, Good practices in combating and eliminating violence against women, United

nations division for the advancement of women (17- 20 May 2005 Vienna, Austria) 23.
} 
prosecuted, with the result that weak attention to DVAW and most of the time women do not achieve justice. ${ }^{1}$ Let us discuss some reason in the following sub-topics and subsequent sub-topics.

\subsubsection{Giving weak attention to investigation and prosecution of DVAW}

As raised repeatedly by informants, the police roles are crucial and have of paramount importance in protection of women against domestic violence. Participants mentioned various reasons in connection with weak attention to DVAW on the parts of police, prosecutors and courts. Although participants mentioned various reasons to the weakness of investigation and prosecution of domestic violence, the topic will discuss the major ones which were mainly and repeatedly pointed out by the participants. Key informants from NGOs and professionals raised that, many police officials have viewed domestic violence as a private matter and pleases best left behind closed doors. This has resulted in attitudes and systems that minimize police responses and discourage specialized responses to women who are victims. Officers who do take action to better meet the needs of women victims of violence have sometimes faced recriminations and social isolation, with their efforts being denigrated. One female police officer told me that,

'Even talking about domestic violence against women as a crime is considered as a shame. I'm working on gender focal person. But I couldn't help women.

Because, most of the time in police station it is disregarded. When I asking

something to help the victim, the commander by himself didn't give attention

unless, the violence is by stranger/outsider and or grave physical injury. When

I repeatedly talking about abused women how to help in meetings they blamed me

and latter even they prevented me from participating some meeting with higher officials", ${ }^{2}$

This reveals that, how much does the issues of domestic abuses were ignored even in the police station. The data shows that, Police have long been under criticism for not doing enough to protect women from domestic violence and for an often apathetic attitude towards the problem.

However, Police should have to aware that, they are at the frontline of the criminal justice system. They are often called upon to intervene when an act of violence is in progress or shortly after it has occurred. Police needs to work with victims, offenders, witnesses and various forms of evidence. Their attitude and response to all involved can have a dramatic impact on ensuring developments of justice system; including the prevention of future domestic violent acts and the protection of victims. But, conversely they left behind of their role to protecting women against domestic violence and even victims believe that nothing and no one can assist them as they remain in abusive settings.

The participants unequivocally explain the reason of weak attention to investigation and prosecution of DVAW especially on the parts of police, prosecutors and courts. It may include; the problem of under required quality of staff, lack of commitment, inconvenience of investigation room, inefficiency amount of budget, reluctance to interfere in private affairs and inadequacy of coordination/relationship among legal institutions. I will try to discuss them one by one in the following sub-topics.

\subsubsection{The Reluctance to Interfere in the Private Sphere}

As we have tried to discuss in proceeding topic, the problem of reluctance have been seen to intervening DVAW. However, such arrogance has of paramount negative effects on protection of WADV. The first reason that the 'go home' attitude is inappropriate is that it reinforces institutionalized acceptance of domestic violence acts as private practices beyond the regulation and control of the state. The police seem to consider domestic violence as a private matter that does not require state interference. The police are also reluctant to intervene in domestic disputes and frequently advise women to return to their husbands. Therefore, it is not uncommon even for women themselves to perceive violence in the private sphere as normal. One police officer, stated that,

" Unless, it is grave physical injury or homicide, interfering in the families affairs are not important.

Because, interfering in the family has resulted to the disturbance

of household. If we interfere and brought the husband before court, he will be sentenced to imprisonment. So who can feed wife and child? It is very problematic. So, most of the time, we opt it to leave.",

From this it is understandable that, interfering in domestic violence is conceived as disturbing households by law enforcement authorities. They give due attention for household unit than women's right. Such conception has an adverse effect on the protection of women against domestic violence.

\subsubsection{The inconvenience of Investigation room for victims and lack of commitments of Police}

As our data divulges that, the inconvenience of investigation room is one of the reasons for weak to DVAW. The inconvenience of investigation room or absences of sensitive criminal proceeding for victims are great problems

${ }^{1}$ FGD conducted with different NGOs, professionals of women and child affairs office, Judge and prosecutors by the researcher on $5,12,10$ \&11 April 2019 respectively.

${ }^{2}$ Interviews conducted with gender focal person of police officer at Jimma town on 2 April 2019

${ }^{3}$ Interview conducted with police officer from investigation department on 20 April 2018. Though this idea is quoted as an example many informants interviewed from the police station reveal similar facts on the reluctance of interventions. 
in zonal districts. Evidence from FGD held in different districts of Jimma zone with prosecutor and Judges displayed that gender sensitive criminal proceeding in particular investigation is not introduced. For instance the setup of police stations and the manner in which police officers interact with complainants of DVAW crimes is not friendly to the victims. One police officer quotes that,

"Many victims come to report the incidence. But couldn't talk what

happened to them due to inconvenience of the room. All police

investigators be seated and investigate in single room. Even to listening

someone by itself is very difficult. In such circumstances they are not

confidently talk their sexual, or physical problems rather prefer to leave

their claim and opt to live in abusive environment."

Observations from the police stations visited during the interview reveals the same. A complainant has to report her case in front of all the police officers including other clients. This creates a sense of awkwardness among victims. Further, as professionals of women and child affair pinpointed, some police officers are quite brutal and at times violate the rights of complainants by using discouraging assertions. The real victims would be embarrassed to talk about the incident. This may discourage women from reporting and pursuing the case before the law.

Lack of commitment and the problem of rent seeking on the part of Police are raised as another problem by many informants. They raised that, most of the time women blame the Police and Public Prosecutor for being slow, lack of commitment, nepotism and bribery. The key informants and participants of the FGDs expressed that the cases presented to the Police did not get the necessary attention in due time as a result of rent seeking. However, though rent seeking has been raise by informants as problems on the law enforcement authorities, the assertion is not much supported by majority of informants on the part of courts and prosecutor rather than on police investigators.

As the participant of FGD from professionals of women and child affairs office in kersa, Jimma town and Gomma elucidate, if perpetrator is a well-known or has money or has relatives from the office no investigation has been commenced up on him. Whenever the Police wanted to take side with perpetrators, it was simple to drop the case, because he/she just order the victim to furnish each and every evidence required rather than conducting investigation by him/her. But it is very difficult and even impossible for the victim to do this.

The discussions made with many participants reveal that, even in normal circumstance, the police order the victim to bring each and everything of evidences, which is highly impossible to do so with a victim. However, such practice is very difficult. It is not violating womens' right only; it may defeat our justice system. According to the Ethiopian criminal procedure code, victims are not obliged to bring everything and each evidences. ${ }^{2}$ The police are empowered to investigate and collect necessary evidence up on the accusations. For instance, Under the South African Domestic Violence Act, the police have an obligation to gather data and report to victims on progress of their cases and explain the legal process to the victim. ${ }^{3}$ On other hand, The data obtained from many participant and informant reveal the existence of different set up of gender focal person in police station and gender focal person in justice office departments in all Jimma districts. But they are not functional as promised to protect womens ADV rather, it is mere set up.

\subsubsection{Lack of required Capacity regarding investigation of DV}

The other point worth mentioning here is that, the problems of capacity of authorities. As raised by the informants from the courts and prosecutors, lack of sufficient capacity of institutions entrusted with the enforcement is a major problem which may be causes for inadequate enforcement of law and policies regarding domestic violence against women. Most of the time, both the judiciary and the institutions of law enforcements in Jimma zone have been characterized by lack of human resources and essential facilities. Police and Public Prosecutors must necessarily be given special training with the view to equip them with the technical and legal capacity to investigate and handle cases of domestic violence against women.

The offences of domestic violence against women are not simple and detectable offences through normal mechanism of investigations. It is committed by perpetrator carefully in absence of any witness and other evidences, behind the closed door. It is very complex in nature, committed repeatedly between the persons closely tied with the relationships of consanguinity/affinity. This in turn needs to high capacity of investigative power with modern and sophisticated equipment of different forensic investigation.

Because, one of the most difficult hurdles to overcome lies in a procedural or evidentiary requirement to justifies responsibility. As data indicates, battered women are required to obtain medical certificate documenting their injuries before they can proceed in court. However, the categories of assault do not always provide an accurate description of the level of injury. For example, forensic reports do not consider the impact of repeated injuries over a period of time, the appropriate measure of psychological injury, or the possibility that the severity

\footnotetext{
${ }^{1}$ Interview conducted with police officer by the researcher on 3 April 2019

${ }^{2}$ Criminal procedure code of Empire of Ethiopia, Proclamation No. 165 of 1969 Article 11-20

${ }^{3}$ UNDAW (n 28 ) 15
} 
of the injury may not be fully recognizable at the time of the examination.

\subsubsection{Weak Co-ordination and inefficiency of multi-agency work}

Undeniably, the co-ordination and assistance of different body to the protection of women against domestic violence is very important. In Jimma zone, there are some attempts to ensure the cooperation of authorities to combat domestic violence and protect women against domestic violence though not effective. There is some endeavour in institutional set-up for joint investigation of different DV offences.

The data obtained from discussions with participants of FGD demonstrate that, there are set ups of joint investigation of police and prosecutors according to BPR (policy). ${ }^{1}$ And also women and child affairs office and courts have a role to protection of women. However, they added that, there is no co-ordination and there are different backlogging cases of women among each other. Many participants from professionals of women and child affair office claim that, if the DV cases reported to near police, they simply send back to the office of womens affair. But, the women's affairs office have no police force, have no power of investigation, and have no power of arresting the perpetrator. This impliedly shows weak co-ordination and unwillingness of the case to investigate on the parts of police and prosecutors. One informant in women and child affairs office quotes that,

"When the women went to police officer or prosecutor to report the abuses committed up on them, these organ don't took the issues as series and not as an obligation to respond. Rather, they simply send them to women and child affairs office. They humbly considering that, the women's matter is the role of our office only. But women's issue is not matter of our office only. It needs cooperation of all stakeholders and law enforcement authorities. "2

Nevertheless, the necessity of inter-agency cooperation and coordination in this field has been unquestionable, as far as the creation of services and support for victims and sanctions for perpetrators requires the interlinking of a number of agencies and services. It has also become apparent that, support to women who often need to cope with a range of practical issues will frequently involve provision of assistance to negotiate many bureaucracies associated with criminal and civil law. In this respect, even advocacy has become one of the core elements in response to violence against women, enabling women to access their rights across multiple systems and agency.

\subsubsection{The absence of exclusive budget allocation for gender focal person}

The other points indicated by many participants of FGD and interviews were the problem of budget which needs to be allocated for the gender focal persons. As we have discussed earlier, there are gender focal persons set up in justice office and police station of Jimma zone districts structurally. Though aim are to work on womens rights and assist womens in every aspects, it is not functional as they are not empowered both legally and financially to do so.

They are not established by law, rather by policy, as such they cannot investigate the abuse committed up on women, they cannot give protection for abused women/victim which may include; facilitating temporary shelter, financial, food and other necessary materials. The participants of interviews conducted with those focal persons specifically indicate that, the problem of budget to assist victim are taken as serious challenges to support abused women. No budget allocated exclusively for those genders focal persons. They solely seeing victim with bare eyes rather than helping them.

\subsubsection{The Problem of court reluctances regarding Domestic Violence}

Though polices are part of a much larger system, the effective involvement of courts and other stakeholder are required to protect women against domestic violence. However, the participants from police and NGOs raise some problems on behalf of court in entertaining the cases of domestic violence against women. The court criticized that, it did not give attention if the cases of DVAW brought to them. They simply refer to the reconciliation and or highly mitigate the punishment below threshold of the sentencing guideline set by Federal Supreme Court. ${ }^{3}$ One judge quotes that,

"Domestic violence is simple issue and temporary matter. It may

arise between any families. Hence unless, the case was serious

bodily injury or death, punishing the husband is amounts to punishing all family. So most of the time, we refer to reconciliation for the betterments of family unit." 4

This clearly shows us that, there is high reluctance around the courts. They insist on the unity of household than punishing the perpetrator. Undeniably, such arguments are encourages the offences of domestic violence. However, as with all legal professionals, judges also need to be well informed on the dynamics of domestic violence and understand the impact of such violence on the victims and on legal proceedings. Protecting the

\footnotetext{
${ }^{1}$ Ethiopian Council of Ministers, The Criminal Justice Administration Policy, (adopted by the Council of Ministers 2011)

${ }^{2}$ Interview conducted with women's and child affairs office by the researcher on 30 March 2019

Federal supreme court sentencing guideline, Ethiopian sentencing regulation No-1/2002 and revised No-2/2006 $<$ https://chilot.me/2013/10/16/revised-federal-supreme-court-sentencing-guideline-no-2-2013/ > accessed 22 April 2019

${ }_{4}^{4}$ An interview conducted with court by the researcher on 10 April 2019
} 
rights and interests of the victims, including the right to protection and safety should have to remain key during court proceedings. Judges need to bear in mind that domestic violence proceedings are likely to differ from other types of violence cases. Domestic violence suffered by the victim will have an impact on the victim's testimony and the evidence used is often different from that of other criminal cases. As data obtained from participants of FGD, there are no specialized courts for domestic violence in Jimma zone which entertain the cases of DVAW bearing in mind the nature and complexity of these offences.

Establishing specialized courts or court processes for domestic violence cases is one way to increase the judiciary's responsiveness to domestic violence. Though levels of specialization are vary widely in different jurisdictions, it has of paramount importance in protection of women. Some jurisdictions have created courts that handle only domestic violence cases; others have altered court processes to ensure more effective processing of domestic violence matters; yet others have specialized staff that provide support to victims. ${ }^{1}$

When we see experiences of different states, there are specialized domestic violence courts in different countries. Such arrangements in turn makes victim to be more confident and give their testimony without any fear of court audience or perpetrator. For instance, in South Africa, Ghana, ${ }^{2}$ in the United States and other specialized domestic violence courts incorporate services for victims along with criminal prosecution. ${ }^{3}$

\subsubsection{Absence of victim's protection}

In the proceeding topics, I have clearly discussed the problem of investigation, prosecution and punishments towards the violence and the reason associated with that. However, under this sub-topic, I will try to discuss the problems of absence of victim's protection in the different institutions. Undeniably, the victim's protection is the major mechanism for encouraging the victims to report the incidence of domestic violence and ensuring prosecution to the perpetrator of domestic violence.

Therefore, victim protections have double importance; one is to prevent the loss of evidences and the other is to rehabilitate the victims from her harms by giving necessary psychological and physical healthy treatments. Accordingly, ensuring greater access to services such as; shelters, counseling or legal assistance, improved presentation of evidence at trial and application of effective measures to protect victims and witnesses may ensure the protection of WADV. Anyone who is beaten at home needs help. This may first of all involve talking about the different options for protection, such as those offered by special assistance facilities which may include specialist advice centers for women or the nation-wide violence against women support hotline.

The data obtained from interviews of different participants reveal that, the pre-trial period represents a heightened risk of further violence to the victim. As such, the privacy, dignity and autonomy of victims has not be respected and enhanced in the legal process. They added that, Woman reporting a crime against her should be subjected to procedures that are humiliating.

Most of the time defendant does not arrested or if arrested released on simple and minor bails. The released defendants are not supervised as much as needed. Consequently, this puts the victim at risk of retaliation and repeat victimization. Victims may also be intimidated into changing their story. If the victim does not feel safe or that her concerns are not addressed, she is not likely to continue being co-operative and testify.

However, many international and regional instruments encourage the victim's protections as the top prioritized agenda. For instance, Article 31 of the Istanbul Convention requests national legal systems to prioritize the safety of victims and their children over the exercise of any visitation or custody rights in cases of domestic violence. ${ }^{4}$ When the victim is involved in both justice systems, close co-ordination should be ensured between family courts and criminal courts. Some countries, such as Spain, have responded to the need to address both civil and criminal issues in the same court. ${ }^{5}$

The safety and the needs of the victim must come first, and should precede any other considerations. Forcing or influencing a victim to go back to the abusive relationship can have severe consequences, including death. If the perpetrator has not been held accountable for his actions or if the root causes of violence have not been addressed, violence will most likely continue. For instance, in Finland, Sweden and Switzerland have enacted 'victim support laws' ${ }^{6}$ that aim to counteract the weak position of victims resulting from their victimization and the justice system's prioritization of rights of defendants. Such laws entitle victims to free legal advice and representation, alongside access to other forms of advocacy and support.

Another approach naked by participants regarding to the victim's protection is domestic violence shelters. All participants nurture that, there is no any shelter provided to the domestic violence victim in Jimma zone. The participant of police officer told me that, they simply send back to their home because of the problem of shelter.

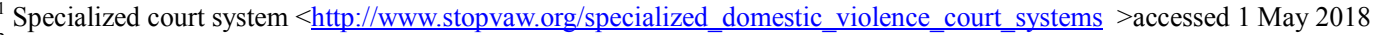

${ }^{2}$ Specialized court system $<$ http://www.refworld.org/docid/560b95c54.html $>$ accessed 1 may 2019

${ }^{3}$ UNDAW (n 28 ) 18

${ }^{4}$ Istanbul convention has been stated in 'Preventing and Combating Domestic Violence against Women, (A learning resource for training law enforcement and justice officers, Council of Europe; January 2016) https://rm.coe.int/CoERMPublicCommonSearchServices/DisplayDCTMContent/ > accessed 22 April 2018

${ }^{5}$ UNDAW(n 28$) 18$

${ }^{6}$ Ibid
} 
They added that they know the problem of sending back the victim, but they have no option.

One female police officer from Jimma town quotes that,

"There is no shelter for victim in Jimma zone. No budget allocated to them.

sometimes if the victim is potentially damaged and or raped by her brother or step father or harmed by fire, I feel personally since iam women.

In such circumstance, I took them to my own house to stay for a moment until she rehabilitate from her injury. But no one can help us or do this since they have no capacity to do rather if they think as humanity. ",

However, the issue of shelter for the victim of DV is not a problem in many countries. It exists in many States and often operated either by local government or NGOs, providing safe accommodation for women who have experienced domestic violence and their children. Shelters commonly provide on-site counseling; victim support, legal assistance and other services victims may need either in the initial time of crisis or when a woman first enters a shelter.

The data congregated through different interviews clearly signpost that, due to the absence of victim's protections, women are often reluctant to seek help from the police and or prefer to stay anonymous when reporting. Because they fear that their privacy and confidentiality will not be safeguarded. They are often ashamed or embarrassed by what they have experienced, especially in cases of sexual abuse or rape. Many women also fear that their abusers will find out about the reporting and kill them, or that their families and communities will humiliate them if they find out. Victims of DV need access to support systems like shelters, legal aid, medical and psycho social support.

The policy framework in Ethiopia provides for a multi-sectoral approach whereby various sectors including non-governmental organizations can come together to provide the required package of support. In line with this, the government has tried to take experiences of different countries ${ }^{2}$ and established a one stop center in different regions. For instance, it has been established in Addis Ababa. ${ }^{3}$ The center was established in April 2012 as a pilot project to help victims of sexual violence, mainly victims of rape by providing all the necessary services such as, medical treatment, legal support, psychological treatment and shelter service in one center. Therefore, it established mainly to provide all the necessary services in one place to victims of violence including victim of domestic violence.

However, the data gathered from the participants of FGD at police station and womens affairs office reveal that, there is some move to introduce one stop service in Jimma town in collaboration with Jimma university hospital though not functional yet. They said that, the selected individual from police station, justice office and women's affairs office have took an experience from Adama town last year to introduce the service center. The center is named 'center for integrated treatments and justice.' It insists on prevention and response to violence and crimes against women and children through integrated services and to bring justice for women and children. The center has aimed to provide free legal support services: investigation, pressing charges and prosecution. But, the data shows that, it is not functional till now rather mere ambitious.

\subsection{The problem of socio-economic, cultural and religious justification for DVAW}

In proceeding focuses, we have seen the problem relating to investigation, prosecution, punishment and absence of victim's protection measures as the main challenges to the protection of womens against domestic violence. However, in this topic, I will try to discuss the problem of socio-economic, socio-cultural and religious justification as challenges to protection of WADV.

The data obtained from participants shows that, women face direct cultural and structural violence through a deeply entrenched system of patriarchy at all tiers of public and private life. The deep rooted attitudes of sociocultural, socio-economic and religious doctrine have been raised as concern for protection of women against domestic violence in Jimma zone. The idea of participant clearly spectacle that, overcoming this challenge requires a changing of arrogant mindset of the society to recognize women's rights as well as needs to making understand the criminality of domestic violence and reacting to it.

Apart from socio-cultural, economic factors also stood out as one of the main factors causing violent behavior in the society and considered as challenges to protection of WADV. All our stakeholders, including key informants and participants of FGD shared that, the lack of economic resources is the root cause of a lot of evils. Poverty is the main reason for sufferings, which stems deprivation of basic needs and thus creates frustration in

\footnotetext{
${ }^{1}$ Interview conducted with police by the researcher on 30 March 2019

${ }^{2}$ Hospital-based responses to sexual assault have existed in some European capital cities and across much of Canada for as long as 15 years. A visit by a Malaysian doctor to St Mary's Sexual Assault Referral Centre in the United Kingdom began the process which resulted in the 'One Stop Shop' concept, which is currently promoted as good practice across Asia and beyond.

${ }^{3}$ AWSAD operates a safe house in Addis Ababa for women fleeing domestic violence. The rehabilitation services provided by the organization include counselling, rights awareness, and skills-development training. Since the establishment of the safe house in 2006, AWSAD has reportedly served 513 women and children. Lawyer Semhal Getachew states that, in addition to the AWSAD safe house, there is only one other shelter in the country. It services immigrants who have returned from the Middle East and is also located in Addis Ababa.
} 
the society. This frustration is then translated through different violent attitudes. Respondents believed that since women are a weaker segment of the society, they are naturally at the receiving end of this frustration. As UN women rights reports, Poverty has been linked to increased violence against women including sexual violence and trafficking. ${ }^{1}$ Economic deprivation is coupled with social injustice which collectively contributes towards frustration and violence.

On other hand, the religious teachings and religious doctrine has imposed some challenges in protection of women. Let us see the challenges of culture, economic and religious law in protections of WADV in the following sub-topics in detail.

\subsubsection{The challenges of status quo/religious laws to the protection of WADV}

According to Ethiopian CSA survey of $2007^{2}$, the dominant religion of Jimma zone populations are Muslim and Christianity. All of them teach their followers according to the laws of religious scripture; Quran and Bible. The participants of FGD and interviews from different professional explain that, most of the time, these religious instruction ensure and approve the male dominance in the parts of societies. It does not encourage women to reacts against abuses by their husband.

For instance, in Christianity, the most radical commandment uttered by Jesus in the Bible is "Love your enemies," then the second most radical of his words must be those on forgiveness. ${ }^{3}$ The issue of forgiveness often arises for victims of abuse. A friend or family member may pressure the victim to forgive any abused committed against them. If not, the victim feels guilty for not being able to forgive the abuser. Accordingly, they undermine the women not to report the abused committed up on them. In such circumstance, the victims opt to live in abusive environment with her abuser. However, neither forgetting nor pretending is possible. Abuse is never forgotten, it becomes a part of the victim's history.

On the other hand, most commonly directives on marriage, based on scripture, are given to women by clergy state that, wives must 'submit' to their husbands, a directive interpreted to elevate the husband/father as the absolute head of the household whom wife and children must obey without question. ${ }^{4}$ Unfortunately, this idea has been misinterpreted to mean that wives and children must submit to abuse from husbands and fathers as well.

In Muslim religion, there are also different instructions which undermine the rights of women against any violence. For instance, A Muslim's belief is to respond to hardships by persevering and by continuing to turn to God for guidance and help. When a person does not lose his/her faith and strives to worship God despite the difficulties, life is presenting. A person who turns away from God in disbelief, or who seeks help from some other deity, will receive punishment in the hereafter. Undeniably, such teaching completely forced women to live with abusive husband without any option. The data gathered from participants of the FGD explain that, in cases of domestic violence, a victim might mistakenly believe that by passively enduring the abuse, she is fulfilling her duty to be patient. As participants of FGD have raised, in the case of domestic violence, abusers often distort or manipulate teachings to rationalize or justify their abusive behavior.

The other point worthy mentioned by many informant is that, the permissibility of polygamous marriages in Muslim religion. Muslim men can marry women up to four (1man-4women ratio). The key informant raise that, many of Muslim men are polygamous. They believe that, polygamous marriages are rights for them and they competes each other to do so. Such religious indoctrination/teaching has great challenges in protecting women against domestic violence. One Judge quotes the polygamous marriages that,

"Muslim men are competing each other for polygamous marriage without any

consideration. They married four women even without having any single ox.

So how they live together peacefully? A Person cannot live without food.

It is quarrel in each single day between each other's and with their husband. ",5

So, from these points, undeniably, it is understandable that, the religious indoctrinations have been seen as the challenges to protection of women against domestic violence in Jimma zone.

\subsubsection{The challenges of socio-cultural justification to DVAW}

Consistent with prior qualitative research, it is clear that women who endorse the traditional gender roles in many society are more likely to be submissive, less likely to have power relation in relationship and more likely tolerate abuse. ${ }^{6}$ At the same time, shame and fear of social stigma often prevent women from reaching out for

${ }^{1}$ UNHCR, Women's Rights are Human Rights, (United Nation Human rights, Office of the High commissioner, New york \& Geneva 2014) 20

${ }^{2}$ Ethiopian 2007 CSA < http://catalog.ihsn.org/index.php/catalog/3583 >accessed 20 April 2018

${ }^{3}$ In the book of Matthew Chapter 18: verse 21, Peter is asking Jesus how many times he should forgive his brother if his brother sinned against him. Peter gave a suggestion implying that seven would be the number of times he should forgive. Jesus' response to Peter was, "I do not say to you, up to seven times, but up to seventy times seven" (Matthew 18:22 NKJV).

${ }^{4}$ This teaching implies sensitivity, "For the husband is the head of the wife as Christ is the head of the Church, his body, and is himself its savior. As the church is subject to Christ, so let wives also be subject in everything to their husbands." (Ephesians 5:23-24, RSV).

${ }^{5}$ Interview conducted with Judges at Jimma town woreda court on 13 April 2019

${ }^{6}$ Myunghan, et al. 'A Hypothesized model of korean women's responses to abuse' (2004) 23 Journal of Tran cultural Nursing, Korea sage 
help. In a patriarchal society, to be a wife and a mother represent key aspects of a woman's identity. The study conducted in Cambodia, pointed out that in developing countries most women cited the stigmatization associated with being unmarried as an additional barrier to leaving abusive relationships. ${ }^{1}$

In Ethiopian most of previous laws, custom and policy were criticized that it has been claimed up on traditional roles of women as wife and mother, and they reinforced the stereotypical domestic-bondage of Ethiopian women. $^{2}$ For many years, the criminal law response to domestic violence has been a legacy of past perception about the violence against women. It has a result of historical and cultural context in which violence against women in domestic sphere has been considered as prerogative of the man to discipline his intimate partner.

As such in the south western Ethiopia, men and women articulated various cultural justifications for domestic violence. As participants conceptualize, a few quotations from their idea illustrate common justifications given for wife beating. The quote illustrates how marriage is customarily construed, the wife being considered equivalent to property over which the husband is free to exercise his will especially in rural areas. One police officer, quotes that,

"She cannot go anywhere without asking her husband's permission.

They believe that he is their owner in all aspects especially in rural.

He supports them; their life depends on him, so, believed that, it is right for

him to beat them. He is the owner of all of her, and he can do anything he wants.",3

Though the legal framework aimed to reaches minimum standards with respect to gender equality and violence against women, including whether customary laws conflict, or are in harmony, with the convention on the elimination of all forms of discrimination against women, the socio-cultural problems are disproportionally challenging the women right protection in Jimma zone.

However, cultural or religious arguments should have never justified violence against women, and local customary laws should be aligned with other legal remedies. Regarding DVAW, customary law must be in compliance with international human rights standards and the convention on the elimination of all forms of discrimination against women. Wherever such laws are in conflict with human rights norms, in particular those of the convention on the elimination of all forms of discrimination against women, the latter must take precedence and be the benchmark for national law reform and national legislation.

\subsubsection{The challenges of Socio-economic problems of women}

The participants frequently mentioned poverty as the main reason for domestic violence and considered as challenges to protection of women. They pointed out that how their dependency on husband's income became worst and vulnerable to violence. This shows the subjugation of women emanates largely from their subordinate economic status. Resources are under the control of men as a result of power imbalance between men and women. This predisposes women to domestic violence and reinforces it.

It was also indicated that, lack of economic resources supports women's susceptibility to violence and their difficulty in get out from a violent relationship. The link between violence and lack of economic resources and dependence is interrelated. On the one hand, the threat and fear of violence keeps women from seeking their own income, or compels them to accept home-based exploitative labor. And on the other hand, without economic independence, women have no power to escape from an abusive relationship. One police officer told me the story of her client that,

\section{'She is completely depending on her husband's income. \\ She forced to tolerate her husband aggressiveness. \\ What could she do? If she was report the incident, abuser seeks divorce. \\ But she don't want divorce. If she divorce, she will have \\ nothing... she don't have any place to go with two \\ children. she have to take him for a while, but at least \\ she raised her children at home, not on the streets". 4}

If a woman is economically dependent, she cannot leave the violent husband even if she wants to leave. It is a common belief that if a woman has her own income, she mayn't trap in abusive relationship and will not worry about supporting herself in the face of separation.

\subsection{Misconception about the problem and criminality of DVAW on parts of women}

As discussed earlier, cultural and social norms are highly influential in shaping individual behaviour, including

publication.

${ }^{1}$ Zimmerman, K. Plates in a basket will rattle: domestic violence in Cambodia, a summary (Phnom Penh, Cambodia, 1995).

${ }^{2}$ Tsehai Berhane sellassie, 'Ethiopian rural women and state' in African Feminism: the political of survival in sub-Saharan Africa (edn)

Mikell Gwendolyn (university of Pennsylvania press 1998)184

${ }^{3}$ Interview conducted with police officer from investigation department by the researcher on 13 April 2019

${ }^{4}$ Interview with police officer from investigation department by the researcher on 13 April 2019 
the use of violence. Norms can protect against violence, but they can also support and encourage the use of violence. The participants of different FGD explain that, Social tolerance of violent behaviour is likely learned in childhood, through the use of corporal punishment, or witnessing violence in the family, in the media, or in other settings.

The data gathered from participants of FGD show that, many women believed that, any violence against them has been considered as legal acts of their husband. Accordingly a man has considered as a right to assert power over a woman and is socially superior. As data obtained from key informant reveal, a man has a right to "correct" or discipline female behaviour. Furthermore, a woman believes that, their freedom should be restricted, Physical violence is an acceptable way to resolve conflicts within a relationship. A woman is responsible for making a marriage work- believing that, sex is a man's right in marriage and girls are responsible for controlling a man's sexual urges.

As discussed so far, domestic violence is not simple issue. Victims of domestic violence have often experienced extreme levels of physical violence, emotional abuse and trauma for months or years before they seek help. However, despite of the fact that, the data obtained from the participants reveal that, given their religious and/or cultural beliefs, victims of domestic violence may believe that abuse is part of every marriage. If the victim has grown up in an environment where domestic violence was condoned, it is more likely that she will stay in the abusive relationship. Victims tend to report the abuse to the police, women's affairs office or social workers only after they have tried unsuccessfully to resolve their disputes in private. Because, as shown by participants of FGD, abused women are usually stay with abusive husband and kept from easily leaving home.

However, as revealed by participants, there are misconceptions of abuse as it need not be reported on the parts of women. Many women believed that, beating, sexually abused, punching, threatening and other violence by their husband are considered as natural obligation up on women. The results indication that awareness related problems such as women not being aware of their rights, society taking DVAW as a norm and the dominant position given to men in society were some of the main reasons raised for misconceptions. This finding shows that there is a need to work on awareness rising on all fronts so as to contain the problem of DVAW.

Some key informants from public prosecutor explain that, they have a mandate to give awareness creation to community regularly and periodically. But, even though, there are such set up in justice office of all districts, its effectiveness to changing the minds of women remain under question till now. Even, women didn't know to where they go if they seek assistance. FGD participants have highlighted that women do not have adequate information regarding where they should go to/report when faced with DVAW cases. As a result even where VAW is committed there is low level of reporting.

As the data gathered reveals, the reason may include the absence of gender centered awareness creation and inefficiency method and less coverage. So, the Existing practices of awareness nurturing should be re-examined to bring about changes in consciousness. Accordingly, regular, targeted and community friendly approaches should be developed.

A culture of silence and secrecy that prevails in Ethiopia has been having a negative influence on women of Jimma zone and discourages them to report and/or disclose violent acts. The stigma attached to going public and disclosing violence and attacks perpetrated on women has made situations even worse and many women would opt to remain silent victims. According to the key informant from police station, even if victim decides to report, she might do it too late. Late reporting gives time to a perpetrator to destroy evidences. It was told that it is very difficult for a victim of violence to reach a police station to file a complaint.

Such Orthodox minds think that a woman should keep her domestic issues to her home since she loses her respect when she brings them out in the streets or to police. Hence, the data indicate that, many abused women suffer in silence, endure physical abuse and remain in the abusive relationship. Victim's awareness are less and reluctances to report to the authorities. Most of the time, even they do not want the abuser to be removed from the home, go to jail or have a criminal record.

\section{Conclusion}

These challenges were mainly drawn from in-depth interview and focused group discussion conducted with different participants. Discussion depicts the challenges and obstacle by pinpointing different legal, practical, socio-cultural, religious and socio-economic challenges to the protection of women and fighting domestic violence against women. Accordingly the challenges of legal lacuna (Legislative challenges), inadequate responses to the DV, socio-cultural, religious and socio-economic problem were depicted.

Regarding the legislative challenges, there are the problems of the scope of coverage of laws dealing with DVAW and extent of punishment. The Ethiopian legal framework falls short of the internationally accepted standards concerning DVAW. Different violence against women does not be criminalized in the way of understanding the complexity nature of the violence, though International standards require States to ensure that forms of violence against women are included in criminal law as criminal acts. The findings show that, FDRE criminal code doesn't criminalize many forms of domestic violence against women which may include; the 
sexual, psychological and economic abuse. And DVAW did not have much attention in this criminal code. It criminalized physical violence only in some extent. But this by itself did not add something to protection of WADV since it simply refers to the provision of ordinary physical injury. Undeniably such legal lacuna may possibly raised as challenges for our justice system in protection of WADV in general and particularly in Jimma zone.

On other hand, Ethiopian law is deprived of civil remedies against domestic violence. There has been no separate domestic violence act or law which provides specific civil remedies for victims/survivors such as right to obtain protection order, monetary/compensation relief, custody order, residence order, shelter or medical benefits or more than one such order.

Regarding the practical challenges, different problems were highlighted in the findings. Which may include; absence of victims protection and giving weak attention to investigation and prosecution due to different reason. Inter alia, the inconvenience of police office/ investigation room for victims- this creates a sense of awkwardness among victims; the problem of under required quality of staff, inefficiency amount of budget, reluctance to interfere in private affairs and inadequacy of coordination/relationship among legal institutions; the problem of reluctance of courts; the absence of victim protection and the other.

In case of victim protection, it has double importance; one is to prevent the loss of evidences and the other is to rehabilitate the victims from her harms by giving necessary psychological and physical healthy treatment. Ensuring greater access to services such as shelters, counseling and legal assistance, improved presentation of evidence at trial and application of effective measures to protect victims and witnesses may ensure the protection of WADV. Such needs special assistance facilities which may include specialist advice centers for women or the nation-wide Violence against women support hotline. However, as findings reveal such protection has not be seen in Jimma zone districts.

Regarding the problem of socio-economic, cultural and religious justification for DVAW - The finding shows that women face direct cultural and structural violence through a deeply entrenched system of patriarchy at all tiers of public and private life in Jimma zone. The deep rooted attitudes of socio-cultural, socio-economic and religious doctrine have been raised as concern for protection of women against domestic violence in Jimma zone. The idea of participants in my findings clearly spectacle that, Overcoming this challenge requires a shift in the conservative mindset and collective thinking the society to recognize women's rights as well needs to making women to understand the criminality of domestic violence and reacting to it properly.

Apart from socio-cultural, economic factors also stood out as one of the challenges to protection of women in the society. The findings reveal that, the lack of economic resources is the root cause of a lot of evils. Poverty is the main reason for sufferings, which stems deprivation of basic needs and thus creates frustration in the society. This frustration is then translated through different violent attitudes. Economic deprivation is coupled with social injustice which collectively contributes towards frustration and violence.

On other hand, the religious teachings and religious doctrine has imposed some challenges in protection of women-most commonly directives on marriage, based on scripture, are given to women by clergy and state that wives must ,submit to their husbands, a directive interpreted to elevate the husband/father as the absolute head of the household whom wife and children must obey without question. It also permits bigamous/polygamous marriage.

The other points are about the problems of Misconception of criminality of Domestic violence against women -The findings show that, many women believed that, any violence against them has been considered as legal acts of their husband. Accordingly a man has considered as a right to assert power over a woman and is socially superior. It is conceived that, a man has a right to correct or discipline female behaviour. Furthermore, a woman believes that, their freedom should be restricted, physical violence is an acceptable way to resolve conflicts within a relationship.

The results indication that awareness related problems such as women not being aware of their rights, society taking DVAW as a norm and the dominant position given to men in society were some of the main reasons discussed as a challenges to protection of women against domestic violence.

\section{Referances}

Abeya SG, Fantahun MA, Worku AY. Intimate partner violence against women in western Ethiopia: prevalence, patterns, and associate d factors' (2011) 11 BMC Public Health

Agumasie Semahegn and Bezatu Mengistie, 'Domestic violence against women and associated factors in Ethiopia; systematic review' (2015) 12 Reprod Health, Published online

Alberta Justice Communications, A Domestic violence handbook for police services and crown prosecutors in Alberta (Edmonton, Alberta ,2014)

Allen, M., \& Devitt, C. 'Intimate partner violence and belief systems in Liberia' (2012) 27 Journal of Interpersonal Violence

Amare Deribew A. Magnitude and risk factors of intimate partner violence against women in agaro town, 
southwest Ethiopia' (2007) Ethiopian J Health Sci

Amie R. Abrams, 'The Collateral Consequences of Masculinizing Violence' (2010)16 WM. \& MARY J. WOMEN \& L.

Anderson, K.L. 'Gender, status, and domestic violence: an integration of feminist and family violence approaches' (1997) 59 Journal of Marriage and the Family, Chicago

Bagshaw, et al, Women, men and domestic violence, University of South Australia, (Vienna, 2000)

Bandura, A. 'The social learning perspective: Mechanisms of aggression' in H. Toch (edn), Psychology of crime and criminal justice .New York: Holt, Rinehart \& Winston (1979)

Bernard Koteen, Gender mainstreaming: Productive tensions in theory and practice, (Sylvia Walby University of Leed, Women's Rights Guide, Cambridge, 2007)

B. C. Meyersfeld, 'Reconceptualizing Domestic Violence in International Law', (2003) 67 Albany Law Review

Boserup, Ester, Woman's Role in Economic Development, (New York, NY: St Martin's Press 1970)

Burgess, R.L. \& Draper, P. 'The explanation of family violence: the role of biological, behavioral, and cultural selection' In L. Ohlin \& M. Tonry (edn.), Family violence (1989) 11Chicago University Press.

Chan, K, 'Assessing the risk of intimate partner violence in the Chinese population: The Chinese risk assessment tool for perpetrator' (2014) 20Violence Against Women

Catharine A. MacKinnon, 'From Practice to Theory, or What is a White Woman Anyway?' (1991)5Yale journal of law

C.A. MacKinnon, 'Equality, Remade,Violence Against Women' (2006)105 Harvard University Press.

Chant, Sylvia. Jane Jaquette and Gale Summerfield(edn),Contributions of a Gender Perspective to the Analysis of Poverty." Women and Gender Equity in Development Theory and Practice: Institutions, Resources, and Mobilization, (Durham, NC: Duke University Press, 2006)

Council of Europe, Preventing and Combating Domestic Violence against Women, (A learning resource for training law enforcement and justice officers, January 2016, Istanbul)

C. Romany, 'State Responsibility goes Private: A Feminist Critique of the Public/Private Distinction in International Human Rights Law' in R. Cook (edn.), Human Rights of Women: National and International Perspectives (University of Pennsylvania Press, Philadelphia, 1994)

Cunradi, et al, 'Alcohol-related problems, drug use, and male intimate partner violence severity among US couples' (2002) 26 Clinical \& Experimental Research

David Levinson, Family violence in cross-cultural perspective (Sage publication, (1989)

Deborah L. Rhode 'sex and violence', in justice and Gender: sex discrimination and law, (Harvard university press, 1991)

Deyessa N, Berhane Y, Alem A, Ellsberg M, Emmelin M, Hogberg U, et al. 'Intimate partner violence and depression among women in rural Ethiopia: a cross-sectional study' (2009) 5 Clinical Practice Epidemiology Mental Health

Doumas, Margolin, \&John , 'The intergenerational transmission of aggression across three generations' 9 Journal of Family Violence, London

Emerson Dobash and Russell P. Dobash, women violence and social changes ( Routledge publisher,1992)

Erulkar A. 'Early marriage, marital relations and intimate partner violence in Ethiopia' (2013) 39 Int perspect sex reprod Health

Feseha G, G/mariam A, Gerbaba M. 'Intimate partner physical violence among women in Shimelba refugee camp, northern Ethiopi' (2012) 12 BMC Public Health

García-Moreno, et al, Global and regional estimates of violence against women: Prevalence and health effects of intimate partner violence and non-partner sexual violence (Geneva, Switzerland, 2013).

Gelles and D.R.Loseke (edn.), Current controversies on Family Violence, (Newbury Park, CA: Sage Publications, 1993)

Heise, L et al, Ending violence against women, population reports, series L, 11. Baltimore (Johns Hopkins University School of Public Health. 1999)

I. Vledder, 'It's in Our Hands: Stop Violence Against Women' in I. Westendorp, Ria Wolleswinkel (edn), Violence in the Domestic Sphere (Intersentia, Antwerpen, 2005)

Jeff Hearn, The violence of men: How men talk about and how agencies respond to men's violence to women (Sage publication, London, 1998)

Kaufman, G. Kantor, \& Jasinski, J. L. Dynamics and risk factors in partner violence: A comprehensive review of 20 years of research. (Thousand Oaks, CA: Sage 1998)

Kebede Deribe et al, 'Magnitude and Correlates of Intimate Partner Violence against Women and Its Outcome in Southwest Ethiopia' (2012) 7 PLoS ONE 4: e36189.

Kimberle Crenshaw, 'Mapping the margin; intersectionality, Idintity political and Violence against Women of color' (1993) 43 Stanford L.Rev

Lara Stemple, 'Human Rights, Sex, and Gender: Limits in Theory and Practice' (2011)8, 31 Pace L.Rev 
Lee Hasselbacher, 'State Obligations Regarding Domestic Violence: The European Court of Human Rights, Due Diligence, And International Legal Minimums of Protection' (2010) 8 Nw. J. Int'l Hum. Rts.

Lena Dominelli, Feminist Social Work; Theory and Practice, ( Palgrave, 2002)

Margi Laird McCue, Domestic violence: A reference Handbook ( $2^{\text {nd }}$ edn, ABC-CLIO publisher, 1995)

Mary Wollstonecraft, 'A Vindication of the Rights of Women' (1975 [1792]) New York: W. W. Norton \& Company,

Megersa Dugasa, 'The Ethiopia's Legal Framework on Domestic Violence against Women: a Critical Perspective' (March 2014) International Journal of Gender and Women's Studies V1. 2 N. 1

Mussie Kassa G/Mehidn, Intimate partner violence: prevalence, risk factors and attitude of men and women in Jimma Zone, Ethiopia ( Master Thesis on Epidemiology and public Healthy, University of Umea, 2006) un published

Orly Richardson, 'Bringing down the bedroom walls: emphasizing substances over form in personalized abuse' (2008) 14 wm \& marry. J of women \& L

Parish, et al. 'Intimate partner violence in China: National prevalence, risk factors and associated health problems' (2004) 30 Int'l Fam Pla Persp,

Pracher M , 'The Marital Rape Exemption: A Violation of a Woman's Right of Privacy' (1981)11 Golden Gate University Law Review

Practice Guidelines :Women and children's family violence counselling and support programs, (Melbourne Victoria Australia, 2008)

The Constitution of the Federal Democratic Republic of Ethiopia, Proclamation No. 1/1995

The Revised Family Code of Ethiopia, Proclamation No. 213/2000

Civil Code of the Empire of Ethiopia, Proclamation No. 165 of 1960

Criminal Code of the Federal Republic of Ethiopia, proclamation no.414/2004

Penal code of the Empire of Ethiopia, Proclamation No. 158 of 1957,

Criminal procedure code of Empire of Ethiopia, Proclamation. No 165, of 1969 